\title{
AKTIVITAS SEDIAAN GEL ANTISEPTIK BERBAHAN AKTIF FRAKSI N- BUTANOL DAUN ALAMANDA (Allamanda cathartica L.)
}

\author{
Anintia Nitami Faradillah, Risna Agustina, Laode Rijai \\ Research and Development FARMAKA TROPICAL Laboratory, Faculty of Pharmacy, \\ Mulawarman University, Samarinda, East Kalimantan \\ Email : anintiafaradillah@ymail.com
}

\begin{abstract}
Various types of viruses, bacteria and fungi stick to the hands every day through physical contact. To prevent the spread of viruses, bacteria and fungi, one of the most appropriate way is washing hands with soap and clean water. Public awareness of hygiene is higher, so hand washings is a necessity. But not all places provide clean water that can be used for hand washing. Appears innovation product called hand sanitizer. Gel is a popular dosage form as hand sanitizer. Alamanda leaf was tested for antibacterial activity against Staphylococcus aureus and Pseudomonas aeruginosa and n-Butanol fraction showed antibacterial activity best at a concentration of 4\%. This study aims to determine the antibacterial activity of $n$-Butanol fraction alamanda leaves after formulated into a gel preparation antiseptics. Testing the antibacterial activity of antiseptic gel formulation made with agar diffusion method using Staphylococcus aureus and Escherichia coli. The results showed that $n$-butanol fraction before formulated has best activity than $n$-butanol fraction after formulated into gel form.
\end{abstract}

Key Words: Allamanda cathartica, Staphylococcus aureus, Escherichia coli, Hand sanitizer

\begin{abstract}
ABSTRAK
Berbagai macam jenis virus, bakteri dan jamur menempel pada tangan setiap harinya melalui kontak fisik. Untuk mencegah penyebaran virus, bakteri dan jamur, salah satu cara yang paling tepat adalah mencuci tangan dengan sabun dan air bersih. Seiring meningkatnya kesadaran masyarakat akan kebersihan, maka mencuci tangan merupakan suatu kebutuhan. Tetapi tidak semua tempat menyediakan air bersih yang dapat digunakan untuk mencuci tangan. Muncul produk inovasi pembersih tangan yang sering disebut hand sanitizer. Gel merupakan salah satu bentuk sediaan yang digemari sebagai hand sanitizer. Daun alamanda telah diuji aktivitas antibakteri terhadap bakteri Staphylococcus aureus dan bakteri Pseudomonas aeruginosa dan fraksi n-Butanol menunjukkan ativitas antibakteri terbaik pada konsentrasi 4\%. Penelitian ini bertujuan untuk mengetahui aktivitas antibakteri fraksi n-Butanol daun alamanda setelah diformulasi menjadi sediaan gel antispetik. Pengujian aktivitas antibakteri sediaan gel antiseptik dilakukan dengan metode difusi agar menggunakan bakteri Staphylococcus aureus dan Escherichia coli. Hasil penelitian menunjukkan bahwa fraksi n-butanol sebelum diformulasi menghasilkan aktivitas yang lebih baik dibandingkan setelah diformulasikan menjadi sediaan gel antiseptik.
\end{abstract}


Kata Kunci: Allamanda cathartica, Staphylococcus aureus, Escherichia coli, Hand sanitizer

\section{PENDAHULUAN}

Infeksi dapat disebabkan oleh bakteri, virus, maupun jamur, dan dapat terjadi di masyarakat (community acquired) maupun di rumah sakit (hospital acquired). Penyakit infeksi menular dan menyebar dengan mudah melalui tangan. Oleh karena itu sering mencuci tangan adalah suatu keharusan untuk menangkal kuman penyebab penyakit yang ditularkan melalui kontak dengan orang lain. Untuk mencegah penyebaran virus, bakteri dan jamur, salah satu cara yang paling tepat adalah mencuci tangan dengan sabun dan air bersih. Namun, dapat juga dilakukan pembersihan tangan dengan bahan aktif alkohol atau bahan antiseptik lainnya. Seiring dengan bertambahnya kesibukan masyarakat, terutama di perkotaan, dan banyaknya produk-produk instan yang serba cepat dan praktis, muncul produk inovasi pembersih tangan tanpa air yang dikenal dengan pembersih tangan antiseptik atau hand sanitizer ${ }^{1}$. Cara pemakain hand sanitizer dengan cara diteteskan pada telapak tangan, kemudian diratakan pada permukaan tangan ${ }^{2}$. Gel merupakan salah satu bentuk sediaan yang digemari sebagai hand sanitizer ${ }^{3}$.

Tumbuhan Alamanda (Allamanda cathartica L.) merupakan salah satu tumbuhan perdu familia Apocynaceae. Kandungan kimia daun alamanda (Allamanda cathartica L.) mengandung senyawa alkaloid dan triterpenoid. Berdasarkan senyawa yang terkandung pada daun alamanda tersebut, telah dilakukan uji aktivitas sebagai antibakteri terhadap bakteri Staphylococcus aureus dan bakteri Pseudomonas aeruginosa.

Berdasarkan penelitian sebelumnya fraksi $n$-butanol daun alamanda yang menunjukkan aktivitas antibakteri terbaik adalah pada konsentrasi 4\%. Berdasarkan uraian latar belakang tersebut diatas, dikembangkan pada formulasi sediaan gel berbasis carbopol yang stabil sebagai antiseptik

\section{METODE PENELITIAN}

\section{Bahan}

Bahan yang digunakan dalam penelitian ini adalah daun alamanda, carbopol, trietanolamin, metil paraben, gliserin, pelarut etanol untuk ekstraksi, pelarut $n$-heksana, etil asetat dan $n$-butanol untuk fraksinasi, paper disc (Whatman No. 42), medium NA (Nutrient Agar) (Merck 1.05450), $\mathrm{NaCl} 0,9 \%$ (Widatra Bakti) sebagai pensuspensi bakteri dan air suling sebagai pelarut. Bakteri uji yang digunakan adalah Escherichia coli dan Staphylococcus aureus.

\section{Peralatan}

Peralatan yang digunakan dalam penelitian ini antara lain, timbangan analitik (Precisa XB 220 A), Gelas kimia $\left(\right.$ Pyrex $^{\circledR}$ ), magnetic stirrer, wadah maserasi, rotary evaporator, waterbath, cawan porselin, labu ukur, corong pisah, mikropipet, autoklaf, inkubator, cawan petri, labu erlenmeyer, spoit injeksi, LAF (Laminar Air Flow), dan mikrometer sekrup.

\section{Prosedur Penelitian}

\section{Pengujian Aktivitas Antibakteri Fraksi n-butanol}

Proses awal yang dilakukan adalah sterilisasi alat yang akan digunakan menggunakan autoklaf pada suhu $121{ }^{\circ} \mathrm{C}$. Setelah itu dibuat medium NA dengan cara melarutkan 5 gram bubuk NA dalam $250 \mathrm{~mL}$ air suling kemudian diaduk dan dipanaskan 
hingga larut. Selanjutnya medium yang telah dibuat disterilkan dengan autoklaf pada suhu $121{ }^{\circ} \mathrm{C}$ sebelum digunakan untuk pengujian. Bakteri uji ditanamkan di atas permukaan agar miring yang telah memadat dalam tabung reaksi dan diinkubasi pada inkubator selama 24 jam pada suhu $37{ }^{\circ} \mathrm{C}$. Setelah 24 jam, dibuat suspensi bakteri dengan menambahkan $\mathrm{NaCl}$ 0,9\% hingga diperoleh pengenceran 1:40.

Pengujian aktivitas antibakteri fraksi daun alamanda dilakukan dengan metode difusi agar. Suspensi bakteri 1:40 sebanyak 0,02 mL dicampur dengan $10 \mathrm{~mL}$ medium NA dalam cawan petri, dihomogen dengan memutar membentuk angka delapan. Ditunggu beberapa saat hingga medium setengah padat. Setelah itu paper disc steril yang sebelumnya telah direndam didalam fraksi n-butanol daun alamanda diletakkan di atas permukaan medium NA. Kemudian diinkubasi pada suhu $37{ }^{\circ} \mathrm{C}$ selama 24 jam. Kontrol negatif digunakan paper disc yang telah direndam didalam air suling sebagai pembanding.

\section{Formulasi Sediaan Gel Antiseptik}

Formulasi sediaan gel dilakukan dengan membuat basis gel carbopol dengan konsentrasi $0,5 \%$ yang dimasukkan kedalam air suling, kemudian ditambahkan trietanolamin sebanyak $0,1 \%$, selanjutnya gliserin sebagai humektan.

Tabel 1. Rancangan Formulasi Gel Basis Carbopol

\begin{tabular}{cc}
\hline Nama bahan & Konsentrasi bahan dalam formula basis Gel (\%) \\
\cline { 2 - 2 } & F1 \\
\hline Carbopol & $0,5 \%$ \\
Trietanolamin & $0,1 \%$ \\
Gliserin & $0,025 \%$ \\
Fraksi n-Butanol & $4 \%$ \\
Air suling hingga & $5 \%$ \\
\hline
\end{tabular}

\section{Pengujian Aktivitas Antibakteri Sediaan Gel Antiseptik}

Proses awal yang dilakukan adalah sterilisasi alat yang akan digunakan menggunakan autoklaf pada suhu $121^{\circ} \mathrm{C}$. Setelah itu dibuat medium NA dengan cara melarutkan 5 gram bubuk NA dalam $250 \mathrm{~mL}$ air suling kemudian diaduk dan dipanaskan hingga larut. Selanjutnya medium yang telah dibuat disterilkan dengan autoklaf pada suhu $121{ }^{\circ} \mathrm{C}$ sebelum digunakan untuk pengujian. Bakteri uji ditanamkan di atas permukaan agar miring yang telah memadat dalam tabung reaksi dan diinkubasi pada inkubator selama 24 jam pada suhu $37{ }^{\circ} \mathrm{C}$. Setelah 24 jam, dibuat suspensi bakteri dengan menambahkan $\mathrm{NaCl}$ 0,9\% hingga diperoleh pengenceran 1:40.

Pengujian aktivitas antibakteri fraksi daun alamanda dilakukan dengan metode difusi agar. Suspensi bakteri 1:40 sebanyak 0,02 mL dicampur dengan $10 \mathrm{~mL}$ medium NA dalam cawan petri, dihomogen dengan memutar membentuk angka delapan. Ditunggu beberapa saat hingga medium setengah padat. Setelah itu paper disc steril yang sebelumnya telah direndam didalam sediaan gel antiseptik diletakkan di atas permukaan medium NA. Kemudian diinkubasi pada suhu $37{ }^{\circ} \mathrm{C}$ selama 24 jam. Kontrol negatif digunakan paper disc yang telah direndam sediaan gel tanpa berisi fraksi n-Butanol sebagai pembanding. 


\section{HASIL DAN PEMBAHASAN}

\section{Pengujian Aktivitas Antibakteri Fraksi n-butanol}

Pengujian aktivitas antibakteri fraksi n-butanol dengan metode difusi agar menggunakan konsentrasi $4 \%$ terhadap bakteri Escherichia coli dan Staphylococcus aureus. Hasil uji fraksi n-butanol daun alamanda dapat dilihat pada Gambar 1.

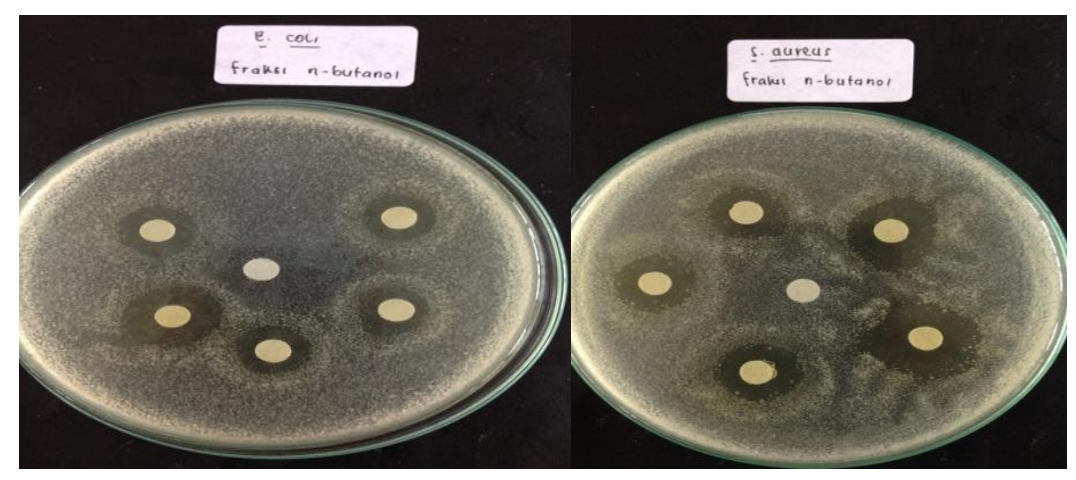

Gambar 1. Uji Aktivitas Antibakteri fraksi n-butanol daun alamanda terhadap bakteri (a) Escherichia coli dan (b) Staphylococcus aureus.

Gambar 1 menunjukkan fraksi n-butanol daun alamanda memiliki aktivitas antibakteri terhadap bakteri Escherichia coli dan Staphylococcus aureus. Hal ini ditandai dengan adanya zona hambat ataupun zona bunuh disekitar paper disc. Kontrol negatif yang digunakan yaitu air suling tidak terbentuk zona hambat maupun zona bunuh sehingga dapat dikatakan bahwa aktivitas antibakteri berasal dari ekstrak bukan dari fraksi.

David Stout (1971) dalam Rita ${ }^{4}$ menjelaskan bahwa suatu antibakteri dikatakan mempunyai aktivitas terhadap bakteri jika mempunyai ketentuan yaitu, luas daerah hambatan $\geq 20 \mathrm{~mm}$ masuk kategori sangat kuat, daerah hambatan antara 10-20 mm masuk kategori kuat, daerah hambatan antara 5-10 mm masuk kategori sedang dan daerah hambatan $\leq 5 \mathrm{~mm}$ masuk kategori lemah.

Data yang menunjukkan zona bunuh yang terbentuk dari hasil aktivitas antibakteri fraksi n-butanol daun alamanda pada bakteri uji dapat terlihat pada Tabel 1.

Tabel 1. Data aktivitas antibakteri fraksi n-butanol

\begin{tabular}{cccc}
\hline \multirow{2}{*}{ Konsentrasi } & \multirow{2}{*}{ Replikasi } & \multicolumn{2}{c}{ Diameter Zona Bunuh (mm) } \\
\cline { 3 - 4 } & R1 & Escherichia coli & Staphylococcus aureus \\
\hline \multirow{2}{*}{$4 \%$} & R2 & 7,53 & 7,46 \\
& R3 & 7,15 & 7,66 \\
& - & 9,36 & 9,88 \\
\hline Air Suling & - & - & - \\
\hline
\end{tabular}

Tabel 1 diatas menunjukkan bahwa aktivitas antibakteri fraksi n-butanol daun alamanda dengan bakteri Escherichia coli dan Staphylococcus aureus termasuk dalam ketegori sedang dengan daerah hambatan antara 5-10mm. 


\section{Formulasi Sediaan Gel Antiseptik}

Formulasi sediaan gel terdiri atas carbopol sebagai gelling agent, gelling agent merupakan bahan pembentuk gel. Carbopol memiliki sifat yang cenderung asam sehingga didalam formulasi ditambahkan triatanolamin (TEA) yang akan menetralkan sifat carbopol. Gliserin digunakan sebagai humektan sebagai humektan yang akan menjaga kestabilan sediaan dengan cara mengabsorbsi lembab dari lingkungan dan mengurangi penguapan air dari sediaan. Selain menjaga kestabilan sediaan, secara tidak langsung humektan juga dapat mempertahankan kelembaban kulit sehingga kulit tidak kering, ${ }^{5,6}$ Air suling berfungsi sebagai pelarut dan ditambahkan fraksi n-butanol yang sebelumnya telah dilarutkan dengan air. Hasil formulasi sediaan gel antiseptik dapat dilihat pada gambar 2 .

Gambar 2. Sediaan Gel Antiseptik
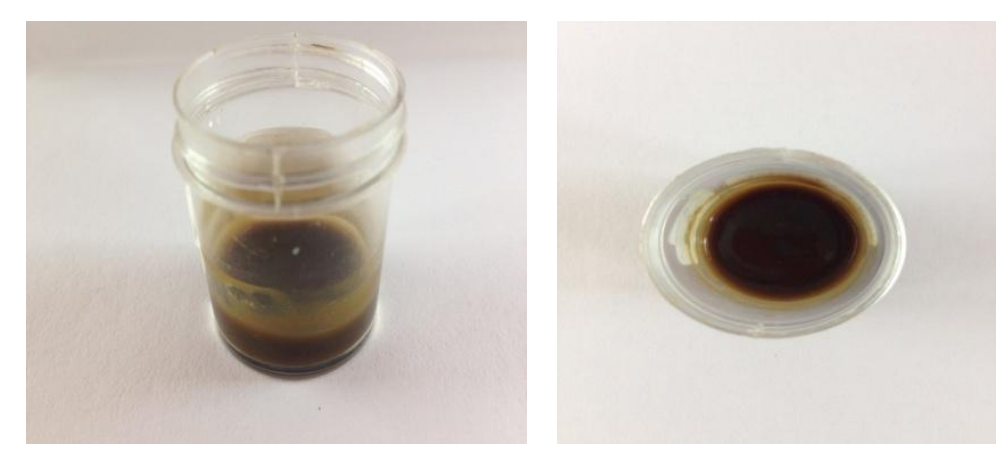

\section{Pengujian Aktivitas Antibakteri Fraksi n-Butanol}

Pengujian aktivitas antibakteri sediaan gel antiseptik dengan metode difusi agar menggunakan konsentrasi $4 \%$ terhadap bakteri Escherichia coli dan Staphylococcus aureus. Hasil uji sediaan gel antisptik fraksi n-butanol daun alamanda dapat dilihat pada Gambar 3.
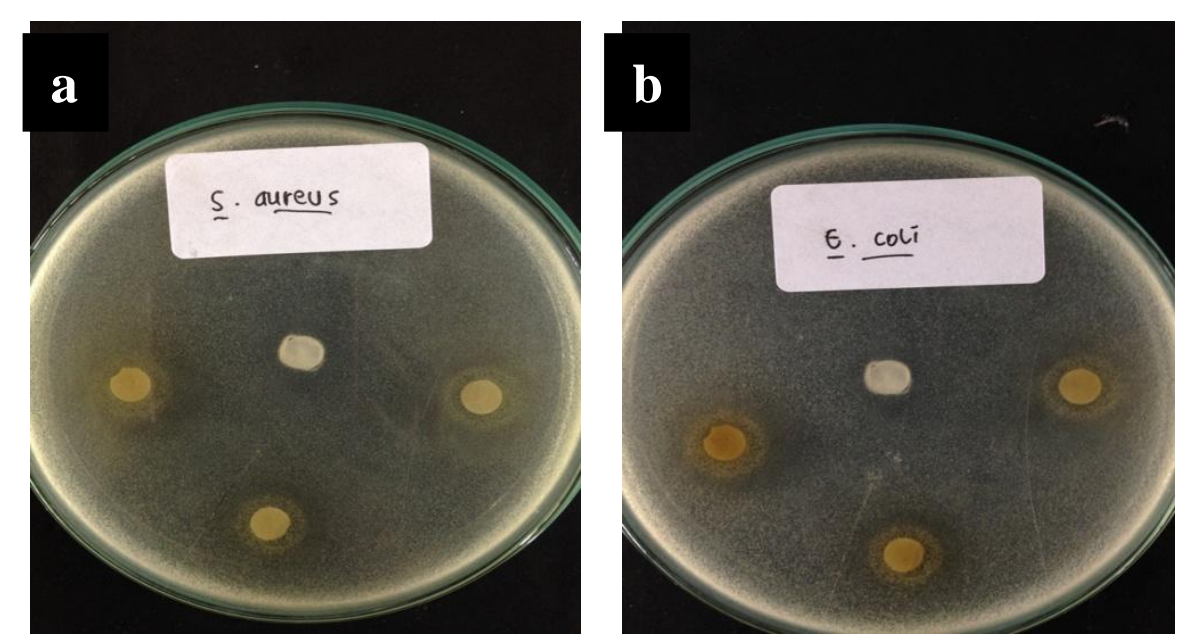

Gambar 3. Uji Aktivitas Antibakteri Sediaan Gel Antiseptik terhadap bakteri (a) Escherichia coli dan (b) Staphylococcus aureus. 
Gambar 3 menunjukkan sediaan gel antiseptik memiliki aktivitas antibakteri terhadap bakteri Escherichia coli dan Staphylococcus aureus. Hal ini ditandai dengan adanya zona hambat ataupun zona bunuh disekitar paper disc. Kontrol negatif yang digunakan yaitu sediaan gel tanpa fraksi n-butanol tidak terbentuk zona hambat maupun zona bunuh sehingga dapat dikatakan bahwa aktivitas antibakteri berasal dari ekstrak bukan dari sediaan gel.

Data yang menunjukkan zona hambat yang terbentuk dari hasil aktivitas antibakteri sediaan gel antispetik daun alamanda pada bakteri uji dapat terlihat pada Tabel 3.

Tabel 3. Data aktivitas antibakteri sediaan gel antiseptik

\begin{tabular}{cccc}
\hline \multirow{2}{*}{ Konsentrasi } & \multirow{2}{*}{ Replikasi } & \multicolumn{2}{c}{ Diameter Zona Hambat (mm) } \\
\cline { 3 - 4 } & & Escherichia coli & Staphylococcus aureus \\
\hline \multirow{2}{*}{$4 \%$} & R1 & 4,89 & 7,61 \\
& R2 & 5,58 & 6,17 \\
& R3 & 6,40 & 6,7 \\
\hline Gel tanpa fraksi & - & - & - \\
\hline
\end{tabular}

Tabel 3 diatas menunjukkan bahwa aktivitas antibakteri sediaan gel antispetik daun alamanda dengan bakteri Escherichia coli dan Staphylococcus aureus termasuk dalam ketegori sedang dengan daerah hambatan antara 5-10mm.

Hasil penelitian menunjukkan bahwa fraksi n-butanol daun alamanda sebelum difromulasi menjadi sediaan gel antiseptik menghasilkan aktivitas yang lebih baik dibandingkan setelah diformulasi menjadi sediaan gel antiseptic, hal ini ditandai dengan terbentuknya zona bunuh pada fraksi n-butanol, sedangkan pada sediaan gel antiseptic menghasilkan zona hambat. Hal ini disebabkan karena sediaan gel yang memiliki tekstur semi solid sehingga kemampuan berdifusi kedalam medium yang memiliki tekstur semi solid lebih rendah dibandingkan fraksi n-butanol yang berbentuk larutan.

\section{KESIMPULAN}

Hasil penelitian menunjukkan bahwa fraksi n-butanol sebelum diformulasi menghasilkan aktivitas yang lebih baik dibandingkan setelah diformulasikan menjadi sediaan gel antiseptik.

\section{DAFTAR PUSTAKA}

1. Iswara, Johan. 2013. Formulasi Sediaan Gel Hand Sanitizer Dengan Bahan Aktif Triklosan 1,5\% dan 2\%. Jurnal Ilmiah Mahasiswa Surbaya. 2. (1)

2. Radji, Maksum, Herman Suryadi dan Dessy Aryanti. 2007. Uji Efektivitas Antimikroba Beberapa Merek Dagang Pembersih Tangan Antiseptik. Majalah Ilmu Kefarmasian.4. (1)

3. Shu, Melisa. 2013. Formulasi Sediaan Gel Hand Sanitizer Dengan Bahan Aktif Triklosan 0,5\% dan 1\%. Jurnal Ilmiah Mahasiswa Surbaya. 2. (1)

4. Rita, Wiwik Susanah. 2010. Isolasi, Identifikasi, dan Uji Aktivitas Antibakteri Senyawa Golongan Triterpenoid pada Rimpang Temu Putih (Curcuma zedoria (Berg.) Roscoe). Jurnal Kimia. 4. (1). 24.

5. Martin, A.J.S., Swarbrick, dan Cammarata, A. 2011. Farmasi Fisika. Edisi 3, diterjemahkan oleh Yoshita. UI-Press. Jakarta. 
6. Barel, A. O., M. Paye, dan H. I. Maibach. 2009. Handbook of Cosmetic Science and Technology. Third Edition. Informa Healthcare USA, Inc. New York. 233, 261-262. 